\title{
The Wild Life of Allan Savory
}

\section{C.J. Hadley}

Reprinted from the Fall issue of Range Magazine, 1999.

\begin{abstract}
Wis Rhodesian biologist has been spreading the gospel of holistic management to the masses on several continents. Some respond to his message. Others deny his successes and ridicule his changes of mind. Is this extraordinary man a genius or simply a contradiction? Is he saving the world or frightening scientists?
\end{abstract}

Allan Savory is a botanist and zoologist with a history as varied as the flora and fauna of the country in which he was born. Rhodesia was a white ruled British territory and when he was a member of the Rhodesia Party Savory broke ranks, crossed the aisle and worked for the black vote. Soon after, he had to flee the country in fear of his life.

He landed in Texas in the early ' 70 s, now lives in New Mexico, but for most of his 63 years, this maverick has been wandering wild places trying to stop desertification, which is a symptom of a worldwide and deadly serious loss of biodiversity.

"As a youngster, my only aim was to live in the African bush forever." He had that opportunity but ended up "forsaking it in order to work toward saving the wildlife that was my reason for being in the bush. Even in the wildest areas, the land was deteriorating, in fact turning to desert, rendering it ever less able to support life of any kind. I was determined to find a way to reverse this process."

He worked as a biologist, soldier, public servant, member of parliament, president of a political party, farmer, rancher, consultant. "Throughout that," says Savory, "there was constantly just one theme-poor land means poor people, social upheaval, political unrest. We farmers and ranchers have destroyed more civilizations than armies have done. Armies change civilizations. We farmers and ranchers destroy them, they never rise again. And I've been obsessed with this problem of why this is happening, why it's happened for $10-15,000$ years, and why we've never been able to stop it.

Biodiversity loss, caused by humans, is taking place at a faster rate than any time in history. "Desertification is a symptom of the loss of biodiversity caused by overloading the air through the burning of fossil fuels, biomass burning, chemicals, fertilizer, agriculture, pollution, burning of national parks and forests," says Savory. "Scientists only have three toolsrest, technology and fire, so they try to justify fire when technology fails, but no fire lit by a human being is natural. Put those three together and those are now threatening not just trees and birds and fish, these are now threatening human survival."

Savory's quest took him a surprising route. He was compelled to work with farmers and ranchers, whose management he believed was responsible for initiating the deterioration. He's on public record in Rhodesia (now Zimbabwe) as saying, "Let's shoot every damn cow and any bloody rancher that stands in the way" because he could see no point of being in the army, and defending his nation, when ranchers were raping it behind him. "My feelings are very, very deep as an environmentalist and I don't particularly like cattle, but I ended running them on my own ranches, which used to be just elephants and lions and buffalo." He did change his mind and has said many times, "The number one public enemy is the cow. But the number one tool that can save mankind is the cow. We need every cow we can get back out on the range. It is almost criminal to have them in feedlots which are inhumane, antisocial, and environmentally and economically unsound."

Constantly searching for new ideas that worked, he thought all that had to be done was to get ecologists into parliament to produce change. "Well, I couldn't produce a scrap of change even when I was president of a political party."

He discovered remorseless spread of deserts and the human impoverishment that always resulted was related to management, but more fundamentally to the way people were making management decisions, whether or not those people lived or worked on the land. "Though our fate as a civilization is tied to the land and its health, and though millions of ordinary people in making their living from the land control that fate to a large degree, unless these people have the support of the hundreds of millions of others who depend on their efforts, they cannot succeed."

He read voraciously. He admires Thomas Samuel Kuhn, who wrote "The Structure of Scientific Revolutions." In it Kuhn talks about science advancing through shifting paradigms. "What he discovered of our scientists, and I know its true of me, is that we have these effects that flow from our deep beliefs and our training. The information which fits our beliefs we see very quickly and easily. The data which does not fit our beliefs is almost invisible to us. We just cannot see it."

It's a deeply held belief that removing cattle from the public lands will heal it. No proof is necessary because it fits the paradigm. It is a deeply held belief that trampling by cattle is destructive to plants and soils; cattle have been blamed for destruction of water points and rivers for thousands of years--because it fits the paradigm.

"General Jan Christiaan Smuts, a botanist by love, a lawyer by training, a soldier and statesman by force of circumstance, a brilliant man, fought through the Boer War and two world wars. Although not an Englishman, he served in the British cabinet. When he was out of office as prime minister of South Africa, he wrote a book called 'Holism and Evolution.' He studied the development of the human personality. It was an 
obsession and he studied how it developed from solid matter through life, mind, to human personality. He pointed out that in this entire development from solid matter there were no parts. He warned us that we would never understand the world until we studied wholes. The concept of a part is totally alien to the world. "Now when you think of it that was staring us in the face." Eroding soil is the biggest single export from the U.S., billions of tons outweighing all grain, timber, military hardware, and commercial products - even with the greatest knowhow in the world. Where there used to be soil cover there is none and all soil cover comes from life. Once there are exposed soils there is erosion, non-effective water cycles, mud slides off California, ever increasing floods in Texas and along the Mississippi. "These floods and this flood damage will just get worse and worse and worse and the deserts will just keep advancing, advancing, advancing until somebody, someday finally understands what I'm saying."

Savory is handsome, serious, jaunty, often sporting khakis, a tweed cap and an impish smile. He can charm easily, but his barbed tongue is just as likely to devastate. He's been called "an abrasive personality," "brilliantly original," "an offshoot of the loony left." He is truly unique. But his tone does not denote his real personality, which is gentle, intellectual and kind. But after more than four decades of research and work, his deep frustrations show because he sees history repeating itself, again, and again.

"We used to burn people at the stake for coming up with truly original work and, tragically, one way or another throughout my life, I've tended to think ahead and come up with stuff that to me seems common sense but to other people seems way out and threatening." When his book, "Holistic Resource Management," was first published, he couldn't even get it reviewed. But it's been selling slowly and consistently and now 17 universities are using the textbook.

Savory's first job in the U.S. was to convince government and academia that desertification was not due to overgrazing or overstocking, as was commonly thought, but due to bad decision-making. "That was a red rag to the bull, to all academics, to all universities." His thought processes were contrary to the deeply held beliefs of ranchers, academics, scientists. "It's the opposite of what people believed so I was roundly condemned." The dean of agriculture at Montana State University once told Savory. "We have no argument with you. We've got to heed the new way, holistic thinking and what you're saying, but our problem is what do we teach? All the textbooks are written the old way."

During a big conference in Rhodesia years ago, someone asked Savory, "Why is there such an intense, almost violent opposition to your thinking? Is it vested interest?" Savory had no answer but someone else said, "Allan, you are up against the biggest vested interest in the world-professional people's egos."

For years there have been anti-desertification conferences around the world, some sponsored by the United Nations. "The developed countries are spending billions to cut the effects of greenhouse gasses," said the Executive Secretary to the UN at the biggest environmental meeting ever held in Africa. "We must show them that desertification is a global environmental problem and if they don't do something they'll feel the consequences themselves..." He also said, desertification" arises from placing too much pressure on the land, often because of overgrazing."

Savory has heard all this before. "That's just like the Royal Navy," he says with a sigh. "Captain James Lancaster sold four ships to India in 1601. He gave the crew on one ship limes and they got no scurvy. The other three ships got no limes and 50 percent of the crew died. That was pretty convincing evidence but because the Royal Navy is a bureaucracy, led by brilliant officers, they discussed and argued about that for approximately 150 years at which point James Lind, a surgeon in the Navy repeated it, and got patients to recover. Then the Royal Navy argued another 49 years before they accepted it." It took the Merchant Marine 70 more years to follow suit.

Nothing has changed. "You are dealing with humans and bureaucracies. Every environmental organization is a bureaucracy. Every university is a bureaucracy. Every one of these international agencies is a bureaucracy. We've gone for nearly 50 years already since we knew that overgrazing was not due to too many animals, since that was first known to science, and we've probably got another 100 years to go before they will accept new scientific thinking."

Savory likes the saying: The whole is greater than the sum of its parts, "but," he says, "when you put brilliant individuals in a bureaucracy it's one of the few exceptions where the whole is less than the sum of the parts."

There is some light. Hundreds of ranchers are working with the Center for Holistic Management (recently renamed the Allan Savory Center for Holistic Management in honor of the man behind the cause). Unfortunately, people in power are still not listening.

This is the age of specialists and one problem is scientists who study a single topic all have very dogmatic opinions. "All of them are probably right, from their point of view, but none of them are seeing the whole. Now when you see the whole, you might get a totally different opinion, but the universities haven't trained scientists to look at the whole. With our scientific ways, if we had a Ph.D. in hydrogen and a Ph.D. in oxygen, we could bring them together to manage water but how much would they know about water? Nothing. They wouldn't even know it existed. It's only now that a theory of chaos is coming in to being-people are beginning to take the word 'holistic' seriously."

Savory asks if I like watching the sun rise. When assured that I do he says, "Well it doesn't rise and it doesn't set, it stays absolutely still and we've known that for 300 years but you've not been able to change. Now that shift in paradigm from a mechanical linear mechanistic world of today's science, to a mind-boggling complex holistic world that only functions in wholes and patterns and energy-for that shift to take place is going to be an even bigger shift than the sun staying still. And we've got to make that shift if we're going to survive as a species."

His teachings are, indeed, a major shift. "Holistic management is a unique, goal-drivien, decision-making process that integrates human values with economic and environmental 
concerns, resulting in management that is proactive and sound-socially, ecologically and economically. Practitioners have learned how to restore the land profitably through practices that mimic nature. Many others have merely sought a more rewarding personal or family life. It has worked in communities - with a common vision that reflects what the people there value and hope to accomplish."

Savory has worked for governments on several continents, including the World Bank in North Yemen. "They believe, as everybody does, that deserts have too much livestock and too many nomads abusing them. I showed them evidence that desertification was human, man-made through inadequate use. The man who headed the team, Wade Gregory, was intrigued because it made sense to him. Rain fell while we were there, an inch of rain, and I was able to take a picture of the flood and the next day was able to take a picture of bone dry ground. Not a meter of that rain was effective and I explained how it was due to rest and not due to overgrazing and there's a consequence of that."

Because they couldn't understand his report, they asked if he would show them examples so he chartered three planes and flew a dozen people around some projects he was doing in the U.S. "I showed them good and bad. Ones that were going well. We went to a Texas ranch in the middle of a drought. We had doubled the livestock, increased by another 209 pairs, cut the supplementary feed in half. It was the only ranch to do it in the whole of Texas that I'm aware of and I showed them grass right up to the water points. They looked at it all and it absolutely blew up in my face. They wrote letters denouncing me and sent them all over the place."

A Frenchman who was there told him years later, "Allan, how naive you were. We had just spent $\$ 20$ billion on anti-desertification work around the world. That group you brought together were our specialists and you took us in the middle of a drought and showed us that! You showed them how clever you were and how stupid they were. Do you expect us to applaud you?"

There have been so many similar ego-deflating success stories that the Center now, as a matter of policy, refuses to do any demonstrations. "We just won't do them because they are counterproductive. The more successful the demonstration, the anger and hatred became worse. And it's heart-breaking if you're trying to move humans into a more constructive course. Humans find it very hard to accept new thinking."

Holistic management decision-making, among other things, has helped increase beef production; in four years grass types jumped from six to 23 on a single range in northeastern New Mexico markedly improving biodiversity; riparian areas have improved along with the watersheds; and ground cover has increased. In Namibia, Savory was given some of the worst farms available, "so I couldn't wreck it. They were very frank about it. They said it was beyond reclamation." He took 4,000 acres and pushed his ideas to the breaking point. He tried to make it fail. "And in 5 years, we couldn't. It just got better and better, and we were producing five times as much meat per acre from what was bare ground where I would have given you $\$ 100$ if you could find a single perennial grass plant. We produced solid perennial grassland with no reseeding, no capital, no anything, just changing the animal behavior and planning the grazing."

When he was exiled, he couldn't return to the test farm for four years and it collapsed. No animals left. Back to bare ground. "That was a very big lesson to me and the mistake was mine. All the years we ran it I flew in frequently and told the managers what to do. Guided them...thought I was teaching them, but I wasn't.

He admits they had become consultant-dependent. They didn't understand why they were doing things. "They said the collapse was due to drought. I told them drought didn't overgraze plants. What did you do when I left? They said, 'Breathed a sigh of relief.' I asked Why? And they said, 'Well, we didn't have to do all that paperwork and planning.' What else? 'We just kept on with the short duration grazing rotation and moved the cattle every one to two days, watching the grass and the cattle.' Well that's enough to wreck anything. You can't do that."

If you've read Savory's books, if you've listened to every talk he's ever given in the U.S., he's always insisted, "Don't do that." But his teaching is complex, and, once again, it's new. And, he says for the zillionth time, "Holistic management is not a grazing system; it's a decision-making process. I have tried to show ranchers it was about decision-making on whether to build fence, how to graze the animals, should you do management intensive grazing, should you do planned grazing? There are a lot of decisions that have to be made. They just couldn't get it. They liked management intensive grazing and did that. Fine. Someday you'll come unstuck. And if you are in a non-brittle environment it will be very forgiving, you'll get away with it probably for your life. You can rotate stock for years and years and not see a problem, but if you're in a brittle environment you'll come unstuck rather quickly." He adds, "We spend too much time on grazing and fencing. We've got to start thinking in different terms. Something beyond production. It has to be about caring.

Savory is asked about collaboration and Coordinated Resource Management Plans. "It's nice to get together but the land isn't deteriorating because we weren't collaborating. And you can't manage holistically without collaborating so it is a first step, but planting willows and doing those things is fiddling while Rome burns. The land was deteriorating because of conventional decision-making. Even after they plant willows, please believe me that the land will continue to deteriorate until they"ve removed the cause of the deterioration." 
He insists that cattle are not the cause. "I am an environmentalist and I' $m$ trained conventionally as a scientist so I grew up hating cows, believing all the conventional myths. But then, from my own work and the work of others, I found that we were wrong. So I changed. Now, until more people change, the land will keep deteriorating. They will publish photographs of improved riparian areas, claim successes, get awards, but let time pass and you will find that I am right."

In major cities in the West, Las Vegas, Nev., and Albuquerque, N.M., and many others, flood control has cost millions of dollars even though there's hardly any rainfall. Albuquerque has nine inches of rain annually but its flood control ditches are enormous. Children have drowned in them. "The reason for the floods around here is because of rest, because the land isn't used. If the land wasn't deteriorating nobody would be getting violent, and the ranchers are causing that deterioration because they insist on continuing to over-rest the land."

He went back to basics. He asked himself what did the forefathers of modern science try to do? They were trying to understand the world. Nature. $\mathrm{He}$ was trying to get people to think holistically and it caused anger, especially with government and university people. He separated scientific specialties in terms of color. When red and blue and yellow and green were mixed together they became gray. What did any scientist know of gray? The answer was nothing.

He figured it was an organizational problem. They didn't even understand each other's jargon. Scientists pulled together, each with their own strength. They formed collaborating terms, all focusing on the natural world. When he wanted to know how much scientists knew about gray, the whole, the answer was nothing. It was a revelation. Integrated resource management started to cross train different disciplines. Highly trained scientists tried to manage world desertification. How much did they know about the whole? Nothing.

"What did we do? We reversed the process. We started from the point of view of gray, that's the whole, your whole resource space, your company, your business. We formed a holistic goal meeting your deepest values to the land, to your resource, to your life. We looked at the experts' opinions, read papers, scientific journals, went back to old knowledge, went to new knowledge, asked the right questions and tested that knowledge to see if it fit the whole. We asked, "Is this the correct way to this? That's what holistic management is about. That's what gave us the breakthrough and it's almost the opposite of all the conventional management in some ways and the beauty of it is that everything good in conventional management is embraced by holistic management. You don't reject anything."

He talks about resting land and non-brittle environments where there's high humidity and high rainfall. "Rest is the most powerful tool known to science to restore biodiversity, so if you rested major fields in England or on the East Coast or West Coast, it would come back to high biodiversity. Now, if you go to the other extreme, the very brittle environments, particularly the low rainfall ones, rest is probably the most destructive tool known to science. Now the Forest Service and The Nature Conservancy and these people are coming in and saying 'Let's leave that to nature' and that, by definition, means resting it, well that's very destructive because it's no longer natural. They don't get it because they don't understand the role of animals in nature."

Rancher George Work attended his first classes in holistic management in 1986 and says now, "After 13 years, I can say it is still the hardest simple thing I have ever tried to do. The lack of success we have had in some areas has not been because holistic management doesn't work; it is because we haven't practiced it properly."

There are many symptoms of biodiversity loss handled as problems. That is wrong. "Noxious plant invasions-if you treat these as a problem you will fail. Leaders in Montana spent over $\$ 50$ million trying to kill knapweed. They may as well proclaim it the state flower because there are now more than ever. That's because it never as a problem; it's only a symptom of the loss of biodiversity. Texans have spent over $\$ 200$ million chaining, poisoning, rooting up mesquite, and there's now more than ever. It never was a problem; it is a symptom of the loss of biodiversity. Small insect, animal outbreaks, locusts, etc.; another symptom. Underground water dries up. Another symptom. A beautiful example of this is the southern part of Africa. Three hundred years ago there were millions and millions of springbok and wildebeest and buffalo and giraffe and all the big game of Africa. Nine inch rainfall. Today, you can travel hundreds of miles and see maybe 50 sheep, 10 head of cattle and it's overstocked, all dried up.

"Next is dying villages and towns. People settle with their families in an area with high biodiversity and they are prosperous in farming and ranching. They form towns, villages, businesses, churches, schools. Then biodiversity starts to go. A butterfly has gone. A bird has gone that used to be there. Old ladies in tennis shoes draw attention to it and we deride them; we are worried about jobs and our cattle and farms. As the biodiversity continues to be lost, so we start to lose farmers and ranchers and the people are not sympathetic. 'Joe was stupid, he was greedy, he overstocked.' As the biodiversity loss continues, the population isn't big enough to support the schools and churches. The villages and towns fold up. The people in cities are not sympathetic. It's more workers for the factory. And as the biodiversity loss continues, finally, the cities fall. Throughout history, that has always happened."

Public enemy number one in the West is cattle. They're blamed for the bulk of these ailments, for causing deserts. The environmental movement has been trying for years to get cattle off the public lands. "You can find this in ancient Hebrew texts 2,000 years ago, blaming the nomads and their animals for causing deserts. It's a human belief of a long period. They are putting methane into the air, which is changing global weather patterns now. The public perception is that they are dripping with fat and oozing chemicals. Even people I respect deeply say you only have to control the three C's-carbon, chainsaws, and cattle. Now it's very serious when you are handling the number one public enemy with the greatest problem that humanity faces threatening our very survival and you are condemned by the top ecologists and scientists in the world."

Savory has taken photographs all around the arid West and 
the results are not detrimental to cattle. What he has found is a horrible and frightening similarity on ranches, on Indian land and on public land. "On one side of the fence we have community property. Nobody loves it, nobody cares for it. There is overstocking, overgrazing, ignorance, greed. Everything that is bad. On the other side of the fence we have the best management that the U.S. can provide. It's the National Park Service. There is no overstocking, there are no cattle, no sheephaven't been for 50 years. There is no stupidity, no ignorance, no greed, no communal ownership and there is all the knowhow of every university in the world. Vast sums of money have been spent on range management and land management. Now after 50 years of totally different treatments-one totally condemned by every ecologist environmentalist and rancher, and the other praised by scientists-unfortunately, you can't tell which is which on a photo of a fenceline between these properties. The results are the same!"

There are hundreds of sites around the West showing similar lack of success with the greatest minds working on the problem. People are in court suing each other over it, lobbyists are fighting each other in the halls of Congress, "and nobody knows what the hell they are talking about. It's time to stop that and start pulling together. It's time to start collaborating and healing and overcoming this terrible worldwide ignorance of this problem. As soon as we can get cattle back on the land where they belong and where we desperately need them, the sooner we can start to heal the land, cultures, societies, villages, etcetera."

The cycles of life are birth, growth, death, and decay, commonly known as a carbon cycle. When biodiversity is lost the cycle is broken. Overgrazing is due to the time of exposure of the plant to the animal and re-exposure of the plant to the animal. When a plant is grazed it is given a few more years of life. "Severe grazing," says Savory, "is absolutely essential to maintain biodiversity."

When scientists stopped the overgrazing of plants by fencing exclosures, the plants all grew, reports were produced, and government regulations and laws were written. Then the scientists went home. "Thank God the plots remained. If you study them today you will find enormous evidence that rest doesn't work in brittle environments. There is biodiversity loss, soil erosion. Births have stopped, the carbon cycle stopped, everything is going to hell. We've removed pack hunter and we've removed herding prey and the whole breaks up. It's a disaster."

Using cattle as a tool, Savory has produced solid perennial grassland on what had become bare ground without any reseeding. "We simulated the predator with livestock and the perennial grassland returned. Just put the whole back, and there it was. You'll find the scientific method never discovers anything. Observant, creative people make discoveries. But the scientific method protects us from cranks like me."

The Center has shared tremendous success with abject failures. "We had success for 15 years then total collapse. Something was still missing. What was missing was the concept of Smuts' 'whole'. We weren't looking at the family. We weren't looking at the community. We weren't looking at people. We were looking at economics and land and cattle and wildlife and it wasn't working."

What he found in hindsight was that all humans use a decision-making model. You use a model but do it subconsciously so you're not even aware of it. You want to go to town? You can go on horse, foot, bicycle, car, or you can hitchhike. There's a whole lot of ways you can go. That's decision-making. What'1l it cost, how cold is the weather, how far is it, how long will it take, what about prestige? What'll my neighbors think if I arrive on a bike and I'm a cowboy? So you use a decision-making model. All civilizations have used that. And what we've found is that the decision-making model that we use is where our fault lay. It took us a long time. If you use the holistic management model, you have goals-production, preservation, rare and endangered species, reduction of knapweed or mesquite or sagebrush, eradication of diseases, problem solving, soil erosion; you have the resources-energy, minerals, water, etc.; and you have tools-technology, fire and rest. Scientists and enviros use the same three tools. It's trained in every university in the world, they are the only three tools acceptable to main line science, and you use your brain, your money and labor. Then you go through decision-making. Is it profitable? Does the cash flow? How quick is it? What are the research findings? What do my peers think? What are the laws and regulations? What's expert opinion?

Holistic management works with the whole--the people, the family, the community, the water base, the wealth. "We have to form a goal, the values of the family, their culture, language, religion. What forms of production will sustain that family or community? Visualizing the future landscape that will sustain those forms of production becomes the goal against which we make decisions. We add two more tools, animal impact and grazing, without which you cannot reverse desertification. That's why cattle are so vital to our futures now."

Long ago, Savory struck incredible opposition when he came to America. "I was one lonely insignificant little scientist with some new thinking and just got this bombardment of antagonism and resistance and hammering and hatred. And you realize you have got to keep your sense of humor, not take yourself too seriously, have good innings, and only look for recognition in your own eyes because you are not going to get it from the outside. Just do the best you can and don't worry about the rest."

The Allan Savory Center for Holistic Management is a non-profit organization devoted to practicing and disseminating information about concerned use of natural resources. The Center provides training for Holistic Management practioners and educators and includes community learning sites in the U.S., Australia, and Zimbabwe. It conducts research such as the use of livestock and wild grazers as an alternative to biomass burning, and manages farms, ranches, and public lands. The Center provides educational materials including a video, textbook, workbook, planning aids and charts, and fincial planning software. They also publish an informative newsletter, "In Practice." Contact Shannon Horst, Exec. Dir., Allan Savory Center for Holistic Management, 1010 Tijeras NW, Albuquerque, NM 87102. 505-842-5252.

$<$ allans@HolisticManagement.org > <www.holisticmanagement.org>

To subscribe to Range Magazine by Visa or Master Card call 1-800-RANGE4U.

A special SRM rate at $\$ 15.00$ for new or renewal.

Range Magazine

P.O. Box 639

Carson City, Nev. 89702-0639 